\title{
Seasonal variation in acceleration and delay of sexual maturation in female mice by urinary chemosignals
}

\author{
L. C. Drickamer
}

Biology Department, Williams College, Williamstown, Massachusetts 01267, U.S.A.

\begin{abstract}
Summary. Data were compiled and analysed from experiments done over a 10-year period on the acceleration and delay of sexual maturation of female house mice by urinary chemosignals from conspecific males and females. Distinct seasonal patterns emerged for control mice treated with water and for both the acceleration of maturation due to a chemosignal in male mouse urine and the delay of maturation which results from treatment with urine from grouped females. Urine from males accelerated puberty during the period March to September, but not during the months of October through February. Urine from grouped females delayed puberty for the months of September to April, but not for the period May through August.
\end{abstract}

\section{Introduction}

Male mouse urine accelerates the onset of first vaginal oestrus in young females (Vandenbergh, 1969; Colby \& Vandenbergh, 1974; Drickamer \& Murphy, 1978). Urine from grouped females delays sexual maturation in females (Drickamer, 1977a, 1982a). We have studied these phenomena for more than a decade. Drickamer (1982b) demonstrated that some aspects of the male urine treatment producing acceleration and the delay resulting from treatment with urine from grouped females were affected by circadian rhythms. I have often suspected that there were also some seasonal variations or circannual patterns in the age of puberty (see Vandenbergh, Whitsett \& Lombardi, 1975; Drickamer, 1977b; Bronson, 1979), both under the control conditions without urine treatment and when the mice were being treated with the urinary chemosignals. Data were therefore compiled across a large number of past experiments involving puberty acceleration by urine from males and delay of puberty by urine from grouped females to test for possible circannual rhythms.

\section{Materials and Methods}

The general methods and animal husbandry practices over the years covered by the compiled data have been consistent. All of the mice used were from a randomly bred closed colony of ICR/Alb house mice begun initially with 120 mated pairs purchased from Ward's Natural Science Establishment (Rochester, NY, U.S.A.). All mice were housed in shoe-box cages of polypropylene measuring $15 \times 28 \times 15 \mathrm{~cm}$ deep with opaque sides and fitted wire lids. Bedding of ground wood shavings was changed once per week. Wayne Lab Blox and water were supplied ad libitum at all times. Animal rooms were maintained at $21-25^{\circ} \mathrm{C}$ and $20-60 \%$ relative humidity on a $12 \mathrm{~h}$ light/ $12 \mathrm{~h}$ dark daily regimen with overhead fluorescent lights on from $06: 00 \mathrm{~h}$ to $18: 00 \mathrm{~h}$.

For mating, two mature (70-150 days of age) female mice were caged with a mature male for 2 weeks. Pregnant females were isolated into individual cages during the week before parturition. All cages were checked daily and births were recorded. On the day after birth (Day 1) each litter was counted, the young were sexed, and reduced to 10 young, at least 3 of which were males. The young 
were weaned 21 days after birth and immediately assigned to a particular treatment in the current experiment.

For measuring sexual maturation each mouse was examined daily from Day 21 until the occurrence of vaginal introitus, when a daily vaginal lavage was instituted until the occurrence of first vaginal oestrus. The vaginal smears were examined immediately with the light microscope and the cellular contents were judged to determine the stage of the oestrous cycle according to the criteria of Rugh (1968) and Vandenbergh (1969).

Acceleration or delay of puberty were accomplished by treating young female mice daily on the external nares with approximately $0.01 \mathrm{ml}$ of the appropriate urine using 3-4 strokes with a small paintbrush. Fresh urine for each treatment was collected daily from 12-20 donor mice and pooled before use. All donors were adults aged 80-180 days. For each set of results with urine the data for the water-treated control group in each experiment were also recorded. The data were then arranged according to the month in which the experiment started and analyses were performed.

\section{Results}

The results (Text-fig. 1) were analysed with parametric $t$ tests; analysis of variance was not possible due to the large discrepancies in sample sizes across the different months. For urine from grouped females there were significant delays in attainment of first vaginal oestrus relative to controls in all months except May through August inclusive. Conversely, after treatment with urine from males, sexual maturation was significantly accelerated relative to controls in all months except those from October to February inclusive. The mean ages for the control mice also varied considerably and in a consistent pattern across the months of the year, being lowest in winter and highest in summer.

\section{Discussion}

The following conclusions may be made based on the foregoing summary of data: (1) the mean age of puberty in control females varies by several days from winter to summer; (2) delay of puberty by the urinary chemosignal from grouped females occurs during fall, winter and early spring, but not during late spring or summer; and (3) treatment with urine from males results in successful acceleration of puberty only during the spring and summer months.

The first conclusion has been reported previously (Drickamer, 1977b). The reasons for the consistent annual variation in age of puberty in untreated mice are not clear. For deer mice (Peromyscus), Drickamer \& Vestal (1973) reported inherent annual rhythms in patterns of reproduction for animals of 3 species from different latitudes and climates. It is possible that there may be some inherent rhythm for one or more of the physiological processes underlying puberty in the house mice. Pennycuik (1972) concluded that there was an inherent seasonal rhythm for reproduction in the house mouse. It is also possible that some subtle environmental cue(s) may be affecting the physiological rhythms. The mice used here are isolated from external daylight and climatic cues, but there may be other cues which are not controlled.

With respect to the second conclusion, Vandenbergh et al. (1975) reported a seasonal variation in uterine weights (growth) for young female house mice; uteri from peri-pubertal females weighed more in the summer months (May-September) than during the winter (November-February). The present findings are in agreement with this earlier report. In contrast, Wilson, Beamer \& Whitten (1980) reported no seasonal differences in uterine weights for females treated with urine from males or with saline. These contrasting results may be explained by strain differences.

The seasonal variation in the ability to accelerate or delay puberty successfully may be attributable to changes in the quantity or quality of the urinary chemosignals from the donor mice, or to the changing sensitivity of the young female mice to the substances in the urine. It is also 

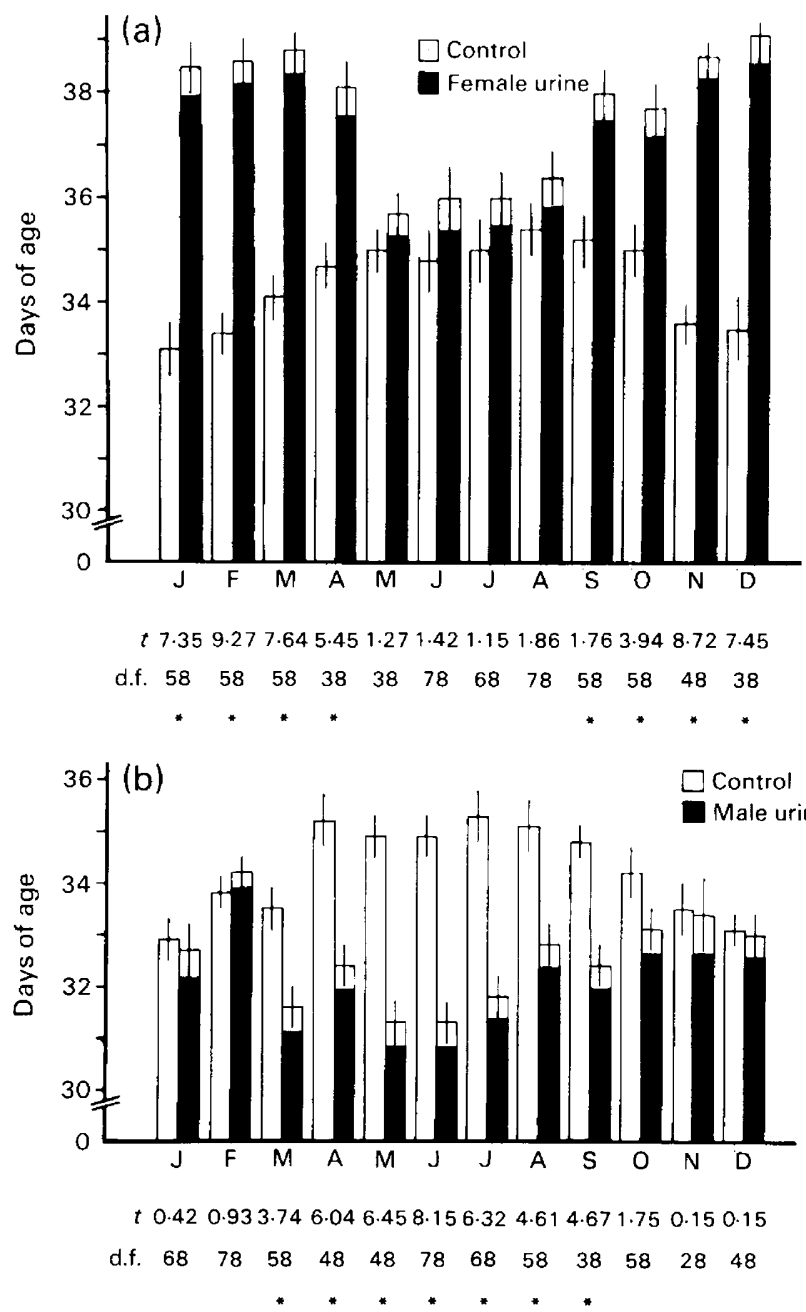

Text-fig. 1. Mean age in days ( \pm 1 s.e.m.) for 12 months for the age of first vaginal oestrus for female house mice caged alone as controls or painted daily on the external nares with (a) urine from intact adult grouped females or (b) urine from intact adult males. A $t$ test value and associated degrees of freedom and probability $\left({ }^{*} P<0.001\right)$ are shown below each monthly pair of bars.

possible that there is an interaction between changes in the donors and changes in sensitivity for the test females.

While house mice living naturally can reproduce throughout the year (Bronson, 1979), under some conditions they show a seasonal pattern of reproductive activity in many regions (Pelikan, 1981). The present findings are seemingly in accord with what would be expected of a seasonal species. That is, acceleration of puberty occurs in the spring and summer months when conditions are presumably better for reproduction, and delay of puberty occurs in fall, winter and early spring when the chances of reproductive success are less. Natural selection may have affected these seasonal patterns of success for the two opposing chemosignal influences on puberty. Clearly, there are selective advantages for delaying puberty in the fall and winter months when low success rates are common and the energy demands for finding food and shelter to survive are paramount. Energy thus conserved might be used in future reproductive endeavours when conditions are more 
propitious. It would also be advantageous to accelerate puberty in spring and summer to utilize the conditions that are more favourable for reproductive activity.

This research was supported in part by United States Public Health Service Grant No. HD08585. I thank the many students and technicians who assisted in gathering the data that are here summarized.

\section{References}

Bronson, F.H. (1979) The reproductive ecology of the house mouse. Quart. Rev. Biol. 54, 265-299.

Colby, D.R. \& Vandenbergh, J.G. (1974) Regulatory effects of urinary pheromones on puberty in the mouse. Biol. Reprod. 11, 268-279.

Drickamer, L.C. (1977a) Delay of sexual maturation in female house mice by exposure to grouped females or urine from grouped females. J. Reprod. Fert. 51, 7781.

Drickamer, L.C. (1977b) Seasonal variation in litter size, body weight and sexual maturation in juvenile female house mice (Mus musculus). Lab. Anim. 11, 159-162.

Drickamer, L.C. (1982a) Delay and acceleration of puberty in female mice by urinary chemosignals from other females. Devl Psychobiol. 15, 433-442.

Drickamer, L.C. (1982b) Acceleration and delay of sexual maturation in female mice via chemosignals: effects of circadian rhythms. Biol. Reprod. 27, 596601 .

Drickamer, L.C. \& Murphy, R.X. (1978) Female mouse maturation; effects of excreted and bladder urine from juvenile and adult males. Devl Psychobiol. 11, 63-72.
Drickamer, L.C. \& Vestal, B.M. (1973) Patterns of reproduction in a laboratory colony of Peromyscus. $J$. Mammal. 54, 523-528.

Pelikan, J. (1981) Patterns of reproduction in the house mouse. Symp. zool. Soc. Lond. 47, 205-230.

Pennycuik, P.R. (1972) Seasonal changes in reproductive productivity, growth rate, and food intake in mice exposed to different regimes of day length and environmental temperature. Aust. J. biol. Sci. 25, $627-635$.

Rugh, R. (1968) The Mouse, Its Reproduction and Development. Burgess Publishing Co., Minneapolis.

Vandenbergh, J.G. (1969) Male odor accelerates female sexual maturation in mice. Endocrinology 84, 658660 .

Vandenbergh, J.G., Whitsett, J.M. \& Lombardi, J.R. (1975) Partial isolation of a pheromone accelerating puberty in female mice. J. Reprod. Fert. 43, 515-523.

Wilson, M.C., Beamer, W.G. \& Whitten, W.K. (1980) Puberty acceleration in mice. 1 . Dose-response effect and lack of critical time following exposure to male mouse urine. Biol. Reprod. 22, 864-872.

Received 12 December 1983 